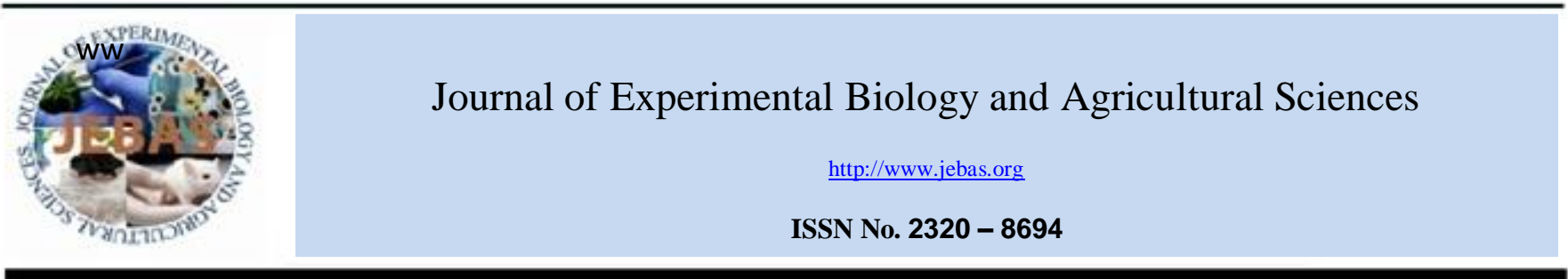

\title{
EFFECT OF THE HEIGHT OF ROOT-STOCK ON THE SUCCESS OF SOFT-WOOD GRAFTING IN SIX CULTIVARS OF MANGO
}

\author{
Deependra Yadav ${ }^{1, *}$, A. K. Pal ${ }^{2}$, S. P. Singh ${ }^{3}$
}

Department of Horticulture, Institute of Agricultural Sciences, Banaras Hindu University, Varanasi-221005, Uttar Pradesh, India.

Received - May 09, 2019; Revision - July 09, 2019; Accepted - July 23, 2019

Available Online - August 05, 2019

DOI: http://dx.doi.org/10.18006/2019.7(4).382.386

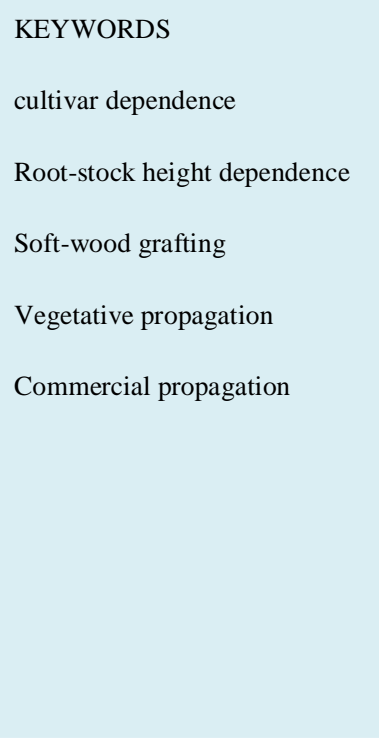

\begin{abstract}
Present study was carried out to investigate the effect of the height of root-stock on the success and growth parameters of grafts employing the method of soft-wood grafting in various varieties of mango scion. The experiment was conducted at the Horticulture Garden, Department of Horticulture, Institute of Agricultural Sciences, Banaras Hindu University, during 2015-16 and 2016-17. The experiment was performed with the mango scion cultivars, Amrapali, Mallika, Dashehari, Chausa, Langra and Bombay Green as the main plot treatments and the root-stock heights, $25 \mathrm{~cm}, 50 \mathrm{~cm}, 75 \mathrm{~cm}$ and $100 \mathrm{~cm}$ as the sub-plot treatments, in split-plot design with 3 replications. Two-way ANOVA statistical analysis was carried out to test significance of different effects. The mango cultivar Langra showed the best results for the percent graft take success, the scion-shoot length, the scion-shoot girth and the number of leaves per plant. Amongst the various tested cultivars, Dashehari performed the best in respect of sprout initiation (12.08 days), Langra performed best in respect of the percent graft take success (69.17\%), scion shoot length $(22.69 \mathrm{~cm})$, scion shoot girth $(17.97 \mathrm{~mm})$ and number of leaves $(25.19)$ per plant; while Chausa showed the highest percent graft survival $(83.67 \%)$. The root-stock of height $100 \mathrm{~cm}$ revealed the best results for the percent graft take success $(66.11 \%)$, the percent graft survival $(82.11 \%)$, the scion-shoot length $(22.60 \mathrm{~cm})$ and the number of leaves per plant $(25.07)$. The grafting done on the 75 $\mathrm{cm}$ height gave the best results for the sprouting time (12.06 days) and the scion-shoot girth $(16.31 \mathrm{~mm})$.
\end{abstract}

* Communicating author

E-mail: deependra1328@gmail.com (Deependra Yadav)

${ }^{1}$ Research Scholar; ${ }^{2}$ Associate Professor; ${ }^{3}$ Professor

Peer review under responsibility of Journal of Experimental Biology and Agricultural Sciences.

Production and Hosting by Horizon Publisher India [HPI] (http://www.horizonpublisherindia.in/).

All rights reserved.
All the articles published by Journal of Experimental Biology and Agricultural Sciences are licensed under a Creative Commons Attribution-NonCommercial 4.0 International License Based on a work at www.jebas.org.

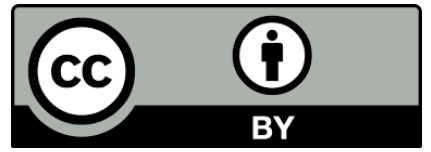




\section{Introduction}

Mango (Mangifera indica L.), a member of the Anacardiaceae family, is a native tree to South Asia from where the Indian or common mango has been distributed worldwide and it has become one of the most widely cultivated fruits in the tropics (Yadav \& Singh, 2017). India is graced with vast germplasm of mango and there are many commercial cultivars at par excellence in quality than the rest of the world. India has plentiful scope for the export of mango pulp and nectar to other countries. Therefore, the mango orcharding promises a lucrative income to India. However, for the economic mango orcharding and growing it is necessary that the cultivars to be planted are productive, of good quality and adaptable to the climate.

Traditionally, the mango is being propagated mainly by seeds. However, the seedling trees never produce the mother plants of the cultivars. The asexual or vegetative propagation methods provide the only way to preserve the unique characters of a genotype and to maintain genetic characteristics of the off-springs (Yadav \& Singh, 2018). The two popular methods of vegetative propagation of mango, namely, budding and grafting are being used for the commercial mango propagation with varying degree of success. The mango propagation by the traditional approach grafting method is cumbersome and time taking. In addition, it has several disadvantages, namely, gradual denudation of the mother plant, non-availability of suitable shoots for grafting, requires a large area for maintenance and has low production per unit area. (Yadav et al., 2018).

For efficient, rapid and commercial mango propagation, a number of detached methods of grafting, namely, cleft, epicotyl, side, softwood, splice and veneer grafting methods have been investigated by several workers (Islam et al., 2004; Pereira et al., 2004; Kumar et al., 2006; Nalage et al., 2010; Sampath et al., 2017; Ullah et al., 2017). The method of soft-wood grafting is one of the simple, quick and inexpensive methods of vegetative propagation. In order to study different graft success and growth parameters, mango grafting has been investigated, in the recent past, employing the soft-wood grafting, by a number of investigators (Prajapati et al., 2014; Karna et al., 2017). The present investigation was carried out to study the influence of height of root-stock on the success and growth parameters of grafts in softwood grafting by the method of cleft grafting in six mango cultivars viz., Amrapali, Mallika, Dashehari, Chausa, Langra and Bombay Green.

\section{Materials and Methods}

The present experiment was conducted at the Horticulture Garden, Department of Horticulture, Institute of Agricultural Sciences, Banaras Hindu University, Varanasi, during 2015-16 and 2016-17, to investigate the success of soft-wood grafting in different cultivars of mango as influenced by the height of the root-stock. The soft-wood grafting was performed using cleft method of grafting, which is the standard and easiest grafting method of mango propagation with very high percent of success (Bilderback et al., 2014).

The experiment was performed with the cultivars of the mango scion as the main plot treatments and the heights of the rootstocks as the sub-plot treatments. The experiment was conducted in split-plot design with 3 replications. The main plot treatments were- Amrapali $\left(\mathrm{V}_{1}\right)$; Mallika $\left(\mathrm{V}_{2}\right)$; Dashehari $\left(\mathrm{V}_{3}\right)$; Chausa $\left(\mathrm{V}_{4}\right)$; Langra $\left(\mathrm{V}_{5}\right)$ and Bombay Green $\left(\mathrm{V}_{6}\right)$ and the subplot treatments were $25 \mathrm{~cm}\left(\mathrm{H}_{1}\right), 50 \mathrm{~cm}\left(\mathrm{H}_{2}\right), 75 \mathrm{~cm}\left(\mathrm{H}_{3}\right)$ and $100 \mathrm{~cm}\left(\mathrm{H}_{4}\right)$ root stock height.

The seed stones were collected from the local market and were sown in the first week of June 2015. The seedlings (root- stocks) were ready for the grafting purpose during the months of JulyAugust of 2016. The scion-sticks for the purpose of grafting were selected from the current season, 6 month old terminalshoots of the six mango varieties viz.,Amrapali $\left(\mathrm{V}_{1}\right)$, Mallika $\left(\mathrm{V}_{2}\right)$, Dashehari $\left(\mathrm{V}_{3}\right)$, Chausa $\left(\mathrm{V}_{4}\right)$, Langra $\left(\mathrm{V}_{5}\right)$ and Bombay Green $\left(\mathrm{V}_{6}\right)$, from the healthy mother trees growing in the Horticulture Garden. The selected scion-shoots were healthy and free from any disease or pest infestation and having healthy buds. The leaves of the bud-sticks were defoliated 7-10 days prior to performing the grafting with the help of secateurs leaving their leaf petioles intact.

The soft-wood grafting was performed employing the cleft grafting method. Various heights of the root-stocks selected for the grafting were, $25 \mathrm{~cm}\left(\mathrm{H}_{1}\right), 50 \mathrm{~cm}\left(\mathrm{H}_{2}\right), 75 \mathrm{~cm}\left(\mathrm{H}_{3}\right)$ and $100 \mathrm{~cm}$ $\left(\mathrm{H}_{4}\right)$. A very sharp grafting knife was used to make a vertical split of 4-8 cm down the centre of the stub to be grafted. The scionsticks with 10-15 cm length and $5-15 \mathrm{~mm}$ diameter, containing 23 buds were selected for the grafting. With the sharp knife the bottom of the bud-stick was cut with two sloping, each in length of $3 \mathrm{~cm}$, on diametrically opposite sides. After proper preparation, the scion was inserted into the cleft of root-stock, taking care that it was held tightly by the pressure of the root-stock itself. The top of the root-stock was wrapped tightly with 200 gauge white polythene strip. As the leaves of the shoots were seen in position to sprout these petioles were detached. Scion shoots of each cultivar were grafted on the same day in order to provide the grafts uniform environmental conditions for the formation of the union. Standard cultural practices were performed in the nursery.

The different parameters selected for assessing the success of the grafting were days taken for the bud sprouting, per cent success of the grafts, per cent survival of the grafts, linear and radial growths of the scion-shoots and number of leaves per graft. To test the 
effects of different variables (cultivars/ heights) on different graft success and graft growth parameters, statistical analysis, namely, 2-way ANOVA (analysis of variance) with replication was performed using the standard method (Panse \& Sukhatme, 1967). The ANOVA computations were performed using two software available online, namely, OPSTAT (Link: 14.139.232.166/opstat/) and two-way ANOVA test Calculator with replication (Link: scistatcalc.blogspot.com/2013/11/two-factor-anova-testcalculator.html)

\section{Results}

\subsection{Graft Success Parameters}

The results of the present study are presented in Tables 1 and 2 . The present investigation revealed that the height of the root-stock and mango cultivar scion significantly affected the time taken for the sprout initiation, however, the root-stock age and scion cultivar interaction did not have any significant effect on the sprouting time. Amongst the tested cultivars, Dashehari $\left(\mathrm{V}_{3}\right)$ has taken the minimum time (12.08 days); while Amrapali $\left(\mathrm{V}_{1}\right)$ took the maximum time (13.61 days) of sprouting. Similarly, out of the 4 root-stock heights, the root-stock with $75 \mathrm{~cm}$ height showed the earliest (12.06 days) sprouting, while the root-stock with $50 \mathrm{~cm}$ height has taken the longest (13.24 days) sprouting time. Out of the 24 combinations, Dashehari $\left(\mathrm{V}_{3}\right) /$ Chausa $\left(\mathrm{V}_{4}\right)$ scion grafted at height $100 \mathrm{~cm}$ of root-stock showed the earliest (11.44 days) sprouting; while Mallika $\left(\mathrm{V}_{2}\right)$ scion grafted at $50 \mathrm{~cm}$ height of root-stock showed the latest (13.78 days) sprouting.

It was observed that the per cent graft success had dependence on the height of the root-stock and scion of mango cultivar significantly; whereas the interaction of the root stock height and scion cultivar were not found to influence it. The highest $(69.17 \%)$ grafting success was reported in the cultivar Chausa, whereas it was the lowest (52.50\%) with Amrapali $\left(\mathrm{V}_{1}\right)$. With regard to the height of the root-stock, the root-stock with $100 \mathrm{~cm}$ height performed the best $(66.11 \%)$, while the root stock with height $50 \mathrm{~cm}$ showed the minimum $(58.89 \%)$ per cent graft take success. The lowest (46.67\%) per cent graft take success

Table 1 Dependence of graft success and growth parameters on the scion of the mango cultivar averaged over height of root-stock

\begin{tabular}{|c|c|c|c|c|c|c|c|}
\hline \multirow[b]{2}{*}{ Treatment } & \multirow{2}{*}{ Cultivar } & \multicolumn{3}{|c|}{ Graft success parameters } & \multicolumn{3}{|c|}{ Graft growth parameters } \\
\hline & & $\begin{array}{l}\text { Number of days } \\
\text { for sprouting }\end{array}$ & $\begin{array}{c}\text { Per Cent } \\
\text { Graft success }\end{array}$ & $\begin{array}{c}\text { Per Cent } \\
\text { Graft survival }\end{array}$ & $\begin{array}{l}\text { Scion-shoot } \\
\text { length }(\mathrm{cm})\end{array}$ & $\begin{array}{l}\text { Scion-shoot } \\
\text { Girth (mm) }\end{array}$ & $\begin{array}{c}\text { Number of } \\
\text { leaves per plant }\end{array}$ \\
\hline V1 & Amrapali & 13.61 & 52.50 & 79.83 & 20.23 & 13.28 & 22.50 \\
\hline V2 & Mallika & 13.39 & 58.33 & 76.58 & 20.00 & 13.16 & 22.44 \\
\hline V3 & Dashehari & 12.08 & 66.67 & 79.92 & 21.56 & 15.68 & 24.45 \\
\hline V4 & Chausa & 12.22 & 66.67 & 83.67 & 22.42 & 15.59 & 24.02 \\
\hline V5 & Langra & 12.28 & 69.17 & 78.25 & 22.69 & 17.97 & 25.19 \\
\hline V6 & Bombay Green & 12.22 & 62.50 & 81.92 & 22.16 & 15.26 & 24.75 \\
\hline & $\mathrm{CD}$ & 0.81 & 6.50 & N/A & 1.97 & 2.53 & 1.75 \\
\hline & $\mathrm{SE}(\mathrm{d})$ & 0.36 & 2.88 & 4.29 & 0.87 & 1.12 & 0.78 \\
\hline & $\mathrm{SE}(\mathrm{m})$ & 0.25 & 2.04 & 3.03 & 0.62 & 0.79 & 0.55 \\
\hline
\end{tabular}

Table 2 Dependence of graft success and growth parameters on the height of the root-stock averaged over the mango cultivar

\begin{tabular}{|c|c|c|c|c|c|c|c|}
\hline \multirow[b]{2}{*}{ Treatment } & \multirow[b]{2}{*}{ Height of root-stock } & \multicolumn{3}{|c|}{ Graft success parameters } & \multicolumn{3}{|c|}{ Graft growth parameters } \\
\hline & & $\begin{array}{l}\text { Number of days } \\
\text { for sprouting }\end{array}$ & $\begin{array}{c}\text { Per Cent } \\
\text { Graft success }\end{array}$ & $\begin{array}{c}\text { Per Cent } \\
\text { Graft survival }\end{array}$ & $\begin{array}{l}\text { Scion-shoot } \\
\text { length }(\mathrm{cm})\end{array}$ & $\begin{array}{l}\text { Scion-shoot } \\
\text { girth (mm) }\end{array}$ & $\begin{array}{c}\text { Number of } \\
\text { leaves per plant }\end{array}$ \\
\hline $\mathrm{H}_{1}$ & $25 \mathrm{~cm}$ & 13.13 & 60.00 & 79.44 & 20.83 & 13.88 & 23.07 \\
\hline $\mathrm{H}_{2}$ & $50 \mathrm{~cm}$ & 13.24 & 58.89 & 76.94 & 20.56 & 14.24 & 23.17 \\
\hline $\mathrm{H}_{3}$ & $75 \mathrm{~cm}$ & 12.06 & 65.56 & 81.61 & 22.03 & 16.31 & 24.56 \\
\hline $\mathrm{H}_{4}$ & $100 \mathrm{~cm}$ & 12.11 & 66.11 & 82.11 & 22.60 & 16.20 & 25.07 \\
\hline & $\mathrm{CD}$ & 0.89 & 4.93 & N/A & 1.38 & 1.16 & 1.09 \\
\hline & $\mathrm{SE}(\mathrm{d})$ & 0.44 & 2.42 & 4.17 & 0.68 & 0.57 & 0.54 \\
\hline & $\mathrm{SE}(\mathrm{m})$ & 0.31 & 1.71 & 2.95 & 0.48 & 0.40 & 0.38 \\
\hline
\end{tabular}

Journal of Experimental Biology and Agricultural Sciences http://www.jebas.org 
corresponded to the variety Amrapali $\left(\mathrm{V}_{1}\right)$ and root-stock of height $25 \mathrm{~cm}$; while the highest $(76.67 \%)$ per cent graft take success corresponded to the combination of Langra $\left(\mathrm{V}_{5}\right)$ with root-stock of height $100 \mathrm{~cm}$.

The per cent graft survival did not significantly depend on either the root-stock height or the scion cultivar or their interactions. The scion cultivar Chausa $\left(\mathrm{V}_{4}\right)$ showed the highest $(83.67 \%)$ while Mallika $\left(\mathrm{V}_{2}\right)$ the lowest $(76.58 \%)$ values for per cent graft survival. The root-stock of height $100 \mathrm{~cm}$ had the highest $(82.11 \%)$ graft survival and that of $50 \mathrm{~cm}$ height showed the lowest $(76.94 \%)$ value for graft survival. The overall maximum $(90.33 \%)$ graft survival corresponded to the combination of Chausa $\left(\mathrm{V}_{4}\right)$ scion with the root-stock of $100 \mathrm{~cm}$ height. The minimum $(66.00 \%)$ graft survival was recorded with combination of Langra $\left(\mathrm{V}_{5}\right)$ scion with the root-stock of height $50 \mathrm{~cm}$.

\subsection{Graft Growth Parameters}

The length of the scion-shoot depended on the height of the rootstock and scion cultivar significantly. However, the interaction effect of the height of the root-stock and the scion of mango cultivar was not found encouraging to affect the scion-shoot length. The cultivar Mallika $\left(\mathrm{V}_{2}\right)$ showed the minimum $(20.00$ $\mathrm{cm})$, while the cultivar Langra $\left(\mathrm{V}_{5}\right)$ exhibited the maximum (22.69 $\mathrm{cm})$ scion-shoot growth. The grafting performed on the root-stock of height $100 \mathrm{~cm}$ recorded the highest $(22.60 \mathrm{~cm})$ length of the scion-shoot and the grafting performed on the root- stock of height $50 \mathrm{~cm}$ showed the lowest $(20.56 \mathrm{~cm})$ length of the scionshoot. The least $(18.91 \mathrm{~cm})$ scion-shoot length was found with the combination of Amrapali $\left(\mathrm{V}_{1}\right)$ with root-stock of height $25 \mathrm{~cm}$, while the highest $(24.00 \mathrm{~cm})$ scion-shoot length was noted in Langra $\left(\mathrm{V}_{5}\right)$ with root-stock of height $100 \mathrm{~cm}$.

The scion-shoot girth also showed significant dependence on the height of the root-stock and the scion of the mango cultivar. However, the interaction effect of the height of the root-stock and the cultivar of the scion was found to influence the scion-shoot length non-significantly. The minimum $(13.16 \mathrm{~mm})$ scion-shoot girth was recorded for the scion cultivar Mallika $\left(\mathrm{V}_{2}\right)$; while the cultivar Langra $\left(\mathrm{V}_{5}\right)$ showed the maximum $(17.97 \mathrm{~mm})$ scionshoot girth. The grafting performed on the root-stock with $75 \mathrm{~cm}$ height exhibited the highest $(16.31 \mathrm{~mm})$ scion-shoot girth; while that with the height $25 \mathrm{~cm}$ exhibited the smallest $(13.88 \mathrm{~mm})$ scion-shoot girth. The overall minimum $(11.80 \mathrm{~mm})$ scion-shoot girth was found with the scion cultivar Mallika $\left(\mathrm{V}_{2}\right)$ grafted on the root-stock with the height $25 \mathrm{~cm}$; while the maximum $(19.00 \mathrm{~mm})$ scion-shoot girth was observed for the scion cultivar Langra $\left(\mathrm{V}_{5}\right)$ grafted on the root-stock with the height $75 \mathrm{~cm}$.

The number of leaves per survived plant was found to be influenced by the height of the root-stock and the scion cultivar, however, the interaction of these two did not influence the number of leaves per graft. The lowest (22.44) number of leaves per plant was observed with Mallika $\left(\mathrm{V}_{2}\right)$ / Dashehari $\left(\mathrm{V}_{3}\right)$ scion, while the scion cultivar Langra $\left(\mathrm{V}_{5}\right)$ yielded the highest (25.19) number of leaves per plant. The minimum (23.07) and maximum (25.07) number of leaves were found with the grafting performed on the root-stocks with heights $25 \mathrm{~cm}$ and $100 \mathrm{~cm}$ respectively. The global minimum (21.11) number of leaves per graft was discerned when Mallika $\left(\mathrm{V}_{2}\right)$ was grafted on the root-stock of height $25 \mathrm{~cm}$, whereas it was the maximum (26.22) in Langra $\left(\mathrm{V}_{5}\right)$ grafted on the root-stock of height $100 \mathrm{~cm}$.

\section{Discussion}

The graft success parameters, in mango grafting in the present investigation, were found to depend on variety of scion. Findings of the present study are corroborated by the results of the investigation performed by a number of previous researchers (Prajapati et al., 2014; Patel et al., 2016; Chaudhary et al., 2017; Kaur, 2017; Bobade et al., 2018). For the majority of grafting parameters viz., success percentage, shoot length, plant height, number of leaves, scion girth and stock girth, survival percentage as well as root girth and length, the performance was observed to significantly depend on the grafting time and height of the rootstock and their interaction (Karna et al., 2017). Higher per cent success and survival percentage at higher root-stock height were recorded in mango (Kumar et al., 2006; Karna et al., 2017). In the present study also the mango graftings performed at higher heights of root-stocks were found to perform better in terms of the graft success and growth parameters. The higher per cent graft success and survival with more grafting height could be a result of higher cambial activity in the hard-wood root-stocks, as compared to soft-wood root-stocks.

Recently, the graft success and graft growth parameters of grafted mango plants were also found to be influenced by rootstock and scion cultivars and the method of grafting (Islam et al., 2004; Pereira et al., 2004; Kumar et al., 2006; Minja et al., 2017). The results of our present study are also supported by a soft-wood grafting study made on the five mango cultivars Langra, Mallika, Totapari, Dashehari and Safeda at three root-stock heights 5, 10 and $15 \mathrm{~cm}$, which revealed that the combination of Dashehari with the root-stock height of $15 \mathrm{~cm}$ showed the highest number of leaves per graft (Jawre, 2012).

\section{Conclusions}

The graft made with the scion of mango cultivar Langra showed the best results for the percent graft take success, the scion-shoot length, the scion-shoot girth and the number of leaves per plant. Dashehari performed the best in respect of sprout initiation and Chausa showed the highest percent graft survival. The cultivar 
Amrapali was found to be the worst in respect of the sprouting time and the percent graft take success; while Mallika yielded the worst results for the $\%$ graft survival, the scion-shoot length, the scion-shoot girth and the number of leaves per plant.

The grafting performed on the root-stock of height $100 \mathrm{~cm}$ revealed the best results for the percent graft take success, the percent graft survival, the scion-shoot length and the number of leaves per plant. The grafting done on the root-stock of $75 \mathrm{~cm}$ height gave the best results for the sprouting time and the scionshoot girth. The graftings performed on the root-stock of height $25 \mathrm{~cm}$ performed the worst for the scion-shoot girth and the number of leaves per plant; while the grafts made on the rootstock of height $50 \mathrm{~cm}$ yielded the worst results for all the GSPs and the scion-shoot length.

\section{Acknowledgement}

Deependra Yadav is thankful to the UGC for the financial help in the form of BHU fellowship.

\section{Conflict of Interest}

Authors would hereby like to declare that there is no conflict of interests that could possibly arise.

\section{References}

Bilderback T, Bir RE, Ranney TG (2014) Grafting and Budding Nursery Crop Plants ; NC State Extension .

Bobade DH, Ingole RH, Kadam A S (2018) Effect of different scion varieties of mango (Mangifera indica L.) on growth and biomass production performance of stone grafts. International Journal of Current Microbiology and Applied Sciences Sp Issue-6: 1642-1648.

Chaudhary P, Prakash S, Kumar A, Singh R (2017) Studies on success of epicotyl grafting as affected by age of seedling rootstock in mango (Mangifera indica L.). Journal of Pharmacognosy and Phytochemistry SP1: 299-303.

Islam MN, Rahim MA, Farooque AM (2004) Standardization of time and grafting techniques in mango under Bangaladesh condition. Asian Journal of Plant Sciences 3 : 378-386.

Jawre R (2012) Response of mango varieties at different height of grafting on rootstock in polyhouse. M. Sc. Thesis submitted to the Jawaharlal Nehru Krishi Vishwa Vidyalaya, Jabalpur (M.P.).

Karna AK, Varu DK, Panda PA, Hota D (2017) Standardization of grafting time and height on success of softwood grafting in mango (Mangifera indica L.). Journal of Pharmacognosy and Phytochemistry 6 : 2803-2807.

Kaur S (2017) Performance of grafts of different scion varieties on local desi rootstock of mango (Mangifera indica L.) under nursery conditions. Chemical Science Review and Letters 6 : 88-93.

Kumar S, Ram S, Singh CP (2006) Growth of Dashehari mango after grafting on different heights of seedling root-stock. Indian Journal of Horticulture 63: 327-329.

Minja RR, Kimaro AA, Mpanda M, Moshy S, Mwaijande V, Ngereza A, Ambrose J, Ndee A, Kihula B, Nyalusi G (2017) Effects of rootstock type and scion cultivar on grafting success and growth of mango (Mangifera indica L.) seedlings. Journal of Experimental Agriculture International 16: 1-9.

Nalage NA, Magar SD, Bhosale SS, Mhetre DA (2010) Effect of height of rootstock on success of epicotyl grafting in mango (Mangifera indica L.) cv. Kesar. International Journal of Agricultural Science 6 : 124-128.

Panse VG, Sukhatme PV (1967) Statistical Methods for Agricultural Workers, $2^{\text {nd }}$ English Ed.; Indian Council of Agricultural Research, New Delhi.

Patel BB, Tank RV, Bhandari AJ (2016) Response of root-stocks and varieties on growth and survival percentage in epicotyl grafting of mango (Mangifera indica L.) The Bioscan 11: 479-483.

Pereira MCT, Viana RC, Correa HCT, Nietsche S (2004) Evaluation of grafting methods in mango trees; Acta Horticulturae 645: 679-683.

Prajapati GK, Patel MM, Bhadauria HS, Varma LR, Modi DJ, Garasiya VR (2014) Study of softwood grafting on different mango varieties. The Asian Journal of Horticulture 9: 240-242.

Sampath PM, Nagesh N, Swamy GSK, Nithin Kumar CJ, Manjunatha Gowda DC, Chongtham AD (2017) Effect of grafting methods on graft success and graft survival of Kari Ishada selections. International Journal of Pure and Applied Bioscience 5: 944-950.

Ullah SS, Malik S, Kumar R, Kumar M (2017) Effect of time and technique of grafting for quality production of nursery plants of Dashehari mango (Mangifera indica L.). International Journal of Current Microbiology and Applied Sciences 6: 685-690.

Yadav D, Pal AK, Singh SP (2018) Vegetative Methods of Plant Propagation: II- Grafting Cutting Layering and Budding in Mango. International Journal of Pure and Applied Bioscience 6: 575-586.

Yadav D, Singh SP (2017) Mango: History origin and distribution. Journal of Pharmacognosy and Phytochemistry 6: 1257-1262.

Yadav D, Singh SP (2018) Vegetative methods of plant propagation: I- cutting layering and budding. Journal of Pharmacognosy and Phytochemistry 7: 3267-3273. 